\title{
Hybrid Extreme Learning Machine dan Firefly Algorithm untuk Meramalkan Nilai Tukar Rupiah terhadap Dolar
}

\author{
Ilham Ramadhani ${ }^{1}$, Auli Damayanti ${ }^{1, *}$ \& Edi Winarko ${ }^{1}$ \\ ${ }^{1}$ Mathematics Department, Faculty of Science and Technology, Universitas Airlangga \\ "Corresponding author: auli-d@ fst.unair.ac.id
}

\begin{abstract}
Every country has a currency as a medium of exchange and the movement of its exchange ratecan affect the economy of the country. In Indonesia, since the freely floating exchange rates system has been applied in August 1997, the value of rupiah currency in the foreign exchange market can change at any time. Considering the massive impacts of exchange rate fluctuation on the economy, then forecastingthe exchange rate of rupiah against the US dollar is important to help Indonesia's economic growth. The aims of this thesis is to predict the estimated exchange rate of rupiah against the US dollar in the future byusing hybrid artificial neural network extreme learning machine (ELM) method and firefly algorithm (FA).In the training process, ELM-FA hybrid has a role to obtain the best weight and bias. The weight and biasthat obtained will be used for forecasting and to know the success rate of the training process, the validation test process is required. Based on the implementation of program and simulation for some parameter values on the exchange rate data from Jan 2015 until Jan 2018, with four input and hidden nodes, and one outputnode, obtained the smallest MSE of the training is 0.000480513 with MSE of the testing is 0.0000854107 .The relatively small MSE value indicates that ELM-FA network is able to recognize the data pattern welland able to predict the test data well.
\end{abstract}

Keywords: extreme learning machine, firefly algorithm, forecasting, rupiah exchange rate.

\section{Pendahuluan}

Prediksi atau peramalan merupakan salah satu hal yang penting dilakukan sebagai upaya mengetahui perkiraan keadaan di masa depan, sebagai contoh meramal nilai tukar mata uang asing. Setiapnegara memiliki mata uang sebagai alat tukar dan pergerakan nilai tukarnya dapat mempengaruhi perekonomian suatu negara, misalnya mempengaruhi harga barang yang dapat memicu terjadinya inflasi. Di Indonesia, semenjak diberlakukannya sistem nilai tukar mengambang bebas (freely floating exchange rates) pada Agustus 1997, nilai mata uang rupiah di bursa valuta asing bisa berubah setiap waktu. Kurs (nilai tukar) mengambang bebas adalah keadaan dimana kurs ditentukan semata-mata oleh penawaran danpermintaan tanpa adanya intervensi pemerintah. Jika pemerintah mengintervensi pasaran valuta asing dengan tujuan mempengaruhi kursnya, maka sistem demikian disebut mengambang terkendali. Perubahan kurs dapat berupa depresiasi dan apresiasi. Kalau harga mata uang suatu negara turun relatif terhadap mata uang asing lainnya, dikatakan bahwa mata uang negara itu mengalami depresiasi 
sedangkan mata uang asingnya mengalami apresiasi [1]. Fenomena yang sering terjadi berhubungan dengan kurs mata uang yaitu fluktuasi nilai mata uang yang tidak menentu. Sebab-sebab yang mempengaruhi tidak stabilnya nilai tukar uang, yaitu faktor politik (kontrol terhadap arus modal dan spreadkurs valas) dan ekonomi makro fundamental (inflasi, suku bunga, situasi neraca pembayaran, trend pertumbuhan pendapatan nasional, pengeluaran pemerintah, dan perubahan jumlah uang beredar) [2].

Amerika Serikat dipandang sebagai negara maju dengan Dolar Amerika Serikat (USD) sebagai mata uangnya. Melalui mekanisme transmisi, inflasi serta suku bunga domestik bisa turun ke tingkat yangrendah. Sebaliknya, dengan menguatnya dolar Amerika Serikat belakangan, nilai rupiah merosot dan berpotensi mendongkrak inflasi. Pergerakan nilai tukar yang fluktuatif ini mempengaruhi perilaku masyarakat dalam memegang uang, selain faktor-faktor yang lain seperti tingkat suku bunga dan inflasi. Kondisi ini didukung oleh laju inflasi yang meningkat tajam dan menurunnya kepercayaan masyarakat terhadap perbankan nasional. Ketidakstabilan nilai tukar mempengaruhi arus modal atau investasi dan pedagangan internasional. Indonesia sebagai negara yang banyak mengimpor bahan baku industri mengalami dampak dan ketidakstabilan kurs ini, yang dapat dilihat dari melonjaknya biaya produksi sehingga menyebabkan harga barang barang milik Indonesia mengalami peningkatan. Dengan melemahnya rupiah menyebabkan perekonomian Indonesia menjadi goyah dan dilanda krisis ekonomi serta kepercayaan terhadap mata uang dalam negeri [3]. Kondisi tersebut semakin membuat nilai tukar dolar Amerika Serikat terhadap rupiah semakin tinggi, karena sebagian besar transaksi internasional di Indonesia menggunakan dolar Amerika Serikat [4].

Mengingat besarnya dampak dari fluktuasi nilai tukar terhadap perekonomian, maka peramalan nilai tukar rupiah terhadap dolar Amerika Serikat penting dilakukan untuk membantu pertumbuhan ekonomi Indonesia. Meramalkan valas (nilai tukar mata uang asing) merupakan strategi yang amat pentingbagi suksesnya usaha bisnis internasional. Ketidaktepatan peramalan atau proyeksi valas dapat melenyapkan peluang merebut laba dari transaksi internasional. Dengan demikian, meramal valas merupakan kunci bagi pengambilan keputusan yang melibatkan transfer dana dari satu mata uang ke matauang lain dalam suatu periode waktu tertentu. Pergerakan kurs valas tergantung dari interaksi berbagai faktor secara simultan. Bagaimana berbagai faktor ini mempengaruhi satu sama lain dan bagaimana merekamempengaruhi pergerakan valas relatif sulit dikuantifikasi maupun diramal. Kurs valas dapat saja bereaksiamat tajam akibat suatu peristiwa yang tidak terduga sebelumnya sehingga menjungkirbalikkan berbagai teori dan ramalan pada periode tersebut [2]. Untuk mendapatkan hasil yang akurat dan stabildiperlukan sebuah metode yang tepat. Metode yang ada pada Artifical Neural Networks, dapat digunakan untuk mempelajari pola dari data historis yang didapatkan [5]. 
Banyak metode Artifical Neural Networks atau Jaringan Saraf Tiruan (JST) yang telah diterapkan dalam peramalan memiliki laju pembelajaran (learning speed) yang rendah sehingga waktu komputasi yangdibutuhkan cenderung lama. Hal tersebut disebabkan oleh penggunaan algoritma pelatihan berbasis gradiendan parameter yang digunakan dalam jaringan ditentukan secara iteratif. Metode pelatihan baru dalam JSTyang disebut Extreme Learning Machine (ELM) diusulkan [6] untuk mengatasi laju pembelajaran yang rendah. ELM memilih secara acak bobot masukan dan bias pada lapisan tersembunyi untuk proses pelatihan dan bobot keluaran diperoleh melalui komputasi. Kinerja metode ELM untuk kasusperamalan lebih baik dibandingkan dengan metode Backpropagation dengan nilai error yang dihasilkan adalah 0.01100 pada ELM dan 0.031933 pada Backpropagation [7].

Dalam penelitian ini diaplikasikan ELM yang merupakan metode dari JST pada peramalan nilai tukar rupiah terhadap dolar Amerika Serikat. ELM merupakan jaringan saraf tiruan feedforward dengan satu hidden layer atau lebih dikenal dengan istilah single hidden layer feedforward neural network (SLFNs). Metode ELM mempunyai kelebihan dalam learning speed, serta mempunyai tingkat akurasi yang lebih baik dibandingkan dengan metode konvensional seperti Moving Average dan Exponential Smoothing. Sehingga dengan menerapkan ELM diharapkan mampu menghasilkan ramalan di masa depan dengan baik [6].

Firefly algorithm (FA) merupakan algoritma yang terinspirasi dari perilaku berkedipnya cahaya kunang-kunang dan cara komunikasi kunang-kunang melalui cahaya yang dimilikinya [8]. Di dalam FA, fungsi tujuan pada permasalahan optimasi yang diberikan berhubungan dengan kerdipan cahaya atau intensitas cahaya yang membantu kawanan kunang-kunang untuk bergerak ke lokasi yang lebih cerah (memiliki daya tarik lebih) untuk memperoleh solusi yang lebih baik. Dalam praktiknya, FA ini konvergen sangat cepat pada iterasi yang kurang dari 80 dan jumlah populasi kunang-kunang yang kurang dari 50, seperti yang telah dijelaskan dalam beberapa penelitian [9].

Pada bidang kecerdasan buatan terdapat istilah swarm intelligence yang diartikan sebagai desain algoritma yang terinspirasi oleh perilaku sosial kolektif koloni serangga dan koloni binatang. FA atau algoritma kunang-kunang merupakan salah satu dari swarm intelligence tersebut. FA memang jauh lebih sederhana baik dalam konsep maupun implementasi. Selain itu firefly algorithm dapat mengungguli algoritma konvensional lainnya seperti genetic algorithm untuk memecahkanbanyak masalah optimasi.

Dengan adanya kekurangan dan kelebihan yang ada pada JST dan FAini, maka menarik untuk dilakukan pengombinasian (hybrid) jaringan saraf tiruan metode ELM dan FA pada proses pelatihan jaringan, agar pencarian bobot dan bias dalam proses pelatihannya menjadi lebih cepat. Dengan demikian setelah proses pelatihan berlangsung, diperoleh 
solusi yang lebih baik sehingga akurat untuk memprediksi nilai tukar rupiah terhadap dolar Amerika Serikat.

\section{Nilai Tukar (Kurs) dan Bursa Valuta Asing}

Kurs atau nilai tukar valuta asing adalah harga mata uang negara asing dalam satuan mata uang domestik. Sebagai contoh, harga mata uang poundsterling Inggris dalam satuan dolar Amerka adalah $\$ 1,80$. Bagi penduduk Inggris, harga dolar Amerika adalah $£ 1 / \$ 1,80=$ $£ 0,56$. Demikian pula, pada saat tertentu, ada kurs tertentu yang berlaku antara mata uang negara satu dengan mata uang negara lainnya di dunia [1]. Nilai tukar (exchange rates) menunjukkan banyaknya unit mata uangyang dapat dibeli atau ditukar dengan satu satuan mata uang lain. Exchange rates tampak dalam surat kabarseksi keuangan setiap hari. Banyaknya US\$ yang diperlukan untuk membeli satu unit mata uang asing disebut direct quotation, sedangkan banyaknya mata uang asing yang dapat dibeli dengan satu dolar Amerika disebut indirect quotation. Sudah menjadi suatu kesepakatan umum bahwa nilai tukar mata uangasing dinyatakan dalam dolar basis [10].

Bursa (Pasar) valuta asing adalah tempat berlangsungnya perdagangan berbagai mata uang negarayang berbeda; di sinilah nilai tukar ditentukan. Pada umumnya, valuta asing diperdagangkan oleh bank- bank serta perusahaan-perusahaan yang berspesialisasi pada bisnis tersebut [1]. Bursa valuta asing yang biasa disebut pula foreign exchange market yang diartikan sebagai lembagapasar di mana orang dapat memperoleh fasilitas-fasilitas untuk melaksanakan pembayaran kepada penduduk negara lain atau menerima pembayaran dari penduduk negara lain. Tidak sedikit pula yang mengartikan bursa valuta asing sebagai tempat di mana permintaan dan penawaran valuta asing dipertemukan [11].

\section{Extreme Learning Machine}

Extreme Learning Machine (ELM) merupakan metode pelatihan baru dari jaringan saraf tiruan. ELM merupakan jaringan saraf tiruan feedforward dengan single hidden layer atau biasa disebut single- hidden layer feedforward neural networks (SLFNs). Metode pelatihan ELM dibuat untuk mengatasi kelemahan-kelemahan dari jaringan saraf tiruan feedforward terutama dalam hal learning speed. Peneliti [6] mengemukakan dua alasan mengapa JST feedforward mempunyai learning speed rendah. Pertama, menggunakan slow gradient-based learning algorithm untuk melakukan training. Kedua, semua parameter pada jaringan ditentukan secara iterative dengan menggunakan metode pelatihan tersebut. Pada pelatihan dengan menggunakan conventional gradient-based learning algorithm seperti backpropagation (BP), semua parameter pada JST feedforward harus ditentukan secara iteratif. Parameter yang dimaksud adalah input weight dan hidden bias. Parameter-parameter tersebut juga saling berhubungan antara 
layer yang satu dengan yang lain, sehingga membutuhkan learning speed yang lama dan sering terjebak pada local minimal. Sedangkan pada ELM parameter-parameter seperti input weight dan hidden bias dipilih secara random, sehingga ELM memiliki learning speed yang cepat dan mampu menghasilkan good generalization performance.

Pada Gambar 1 digambarkan arsitektur jaringan ELM yang merupakan jaringan saraf tiruan feedforward dengan single hidden layer. Pada jaringan tersebut, selain terdapat node-node input, tersembunyi (hidden), dan output juga terdapat bias yang diberikan pada node-node tersembunyi dilambangkan dengan $b$. Bobot antara node input dan node hidden dilambangkan dengan $a$. Jaringan ELMmemiliki $n$ node input dengan $L$ node hidden dan sebuah node output. Neuron input dilambangkan dengan $X$, node hidden dilambangkan dengan $G$, dan node output dilambangkan dengan $Y$. Sedangkan untuk bobot antara $G$ dan $Y$ dilambangkan dengan $\beta$.

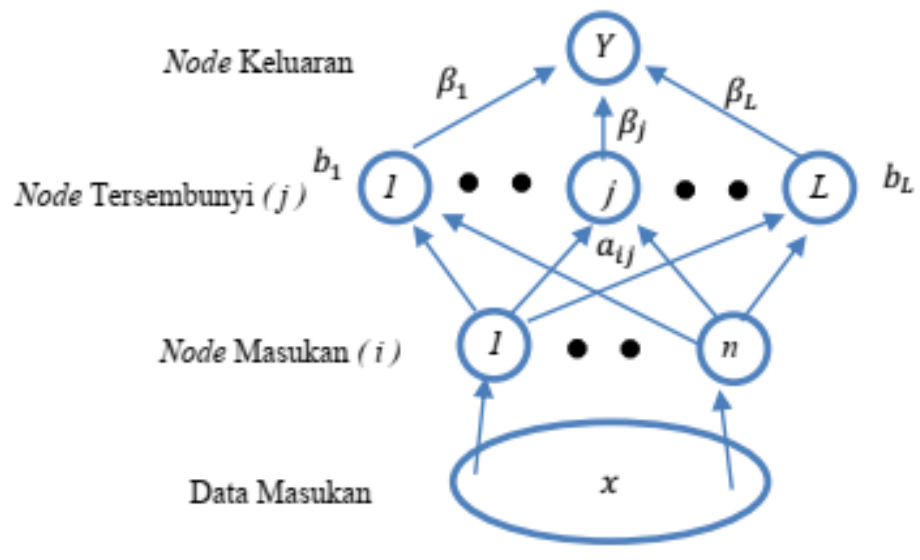

Gambar 1. Arsitektur ELM

Untuk menghitung output dari hidden layer dapat digunakan persamaan (1) :

dengan

$$
G\left(a_{j}, x, b_{j}\right)=g\left(\sum_{i=1}^{n} a_{i j} x_{i}+b_{j}\right), \quad j=1, \ldots, L
$$

$L=$ jumlah neuron hidden

$n=$ jumlah input neuron

$a_{j}=\left(a_{1 j}, a_{2 j}, \ldots, a_{n j}\right)$

$x=\left(x_{1}, x_{2}, \ldots, x_{n}\right)$

Sedangkan untuk menghitung output jaringan dapat digunakan persamaan (2) : 


$$
Y=\sum_{j=1}^{L} \beta_{j} G\left(a_{j}, x, b_{j}\right)
$$

Untuk jumlah pola data sebanyak $p$ dan jumlah neuron hidden sebanyak $L$, dapat disusun sebuah matriks $H y a n g$ beranggotakan keluaran dari lapisan tersembunyi yang berukuran $p \times L$. Matriks $H$ tersebut dapat dinyatakan dalam persamaan (3) :

$$
H=\left[\begin{array}{cccc}
G\left(a_{1}, x^{1}, b_{1}\right) & G\left(a_{2}, x^{1}, b_{2}\right) & \ldots & G\left(a_{L}, x^{1}, b_{L}\right) \\
\vdots & \vdots & & \vdots \\
G\left(a_{1}, x^{p}, b_{1}\right) & G\left(a_{2}, x^{p}, b_{2}\right) & \ldots & G\left(a_{L}, x^{p}, b_{L}\right)
\end{array}\right]
$$

dengan $x^{p}=\left(x_{1}, x_{2}, \ldots, x_{n}\right)$ adalah data input pola ke $-p$.

Proses pelatihan jaringan saraf tiruan metode ELM adalah sebagai berikut (Sun, dkk., 2008):

1. Input data pelatihan yang telah dinormalisasi sebagai node masukan $\left(x_{1}, x_{2}, \ldots, x_{n}\right)$ dan tentukan fungsi aktivasi serta jumlah neuron pada lapisan tersembunyi.

2. Inisialisasi bobot masukan $\left(a_{i}\right)$ dan bias $\left(b_{j}\right)$ secara acak.

3. Hitung setiap keluaran dari node pada lapisan tersembunyi dan dilambangkan dengan $\left(a_{j}, x, b_{j}\right)$. Kemudian disusunlah sebuah matriks $H$ yang beranggotakan semua keluaran dari node pada lapisan tersembunyi $G\left(a_{j}, x, b_{j}\right)$.

4. Bobot akhir $\left(\beta_{j}\right)$ yang menghubungkan lapisan tersembunyi dan lapisan keluaran dihitung dengan persamaan (4):

$$
\beta=H^{+} T
$$

dengan $\mathrm{H}^{+}$merupakan moore penrose generalized invers dari matriks $H$ dan $T$ merupakan vektor target.

5. Hitung semua keluaran di node pada lapisan keluaran dengan persamaan (2).

6. Menghitung nilai Mean Square Error (MSE).

7. Memeriksa kondisi penghentian. Untuk memeriksa kondisi penghentian dapat dilakukan dengan dua cara, yaitu:

i. Membatasi jumlah iterasi (epoch) yang diinginkan

ii. Membatasi error

8. Jika error atau iterasi belum terpenuhi, maka lakukan kembali langkah 2 dan seterusnya.

Proses uji validasi jaringan saraf tiruan metode ELM adalah sebagai berikut [12]:

1. Input data pengujian yang telah dinormalisasi sebagai node masukan $\left(x_{1}, x_{2}, \ldots, x_{n}\right)$.

2. Inisialisasi bobot dan bias yang diperoleh dari algoritma pelatihan. 
3. Hitung setiap keluaran dari node pada lapisan tersembunyi dan dilambangkan dengan $\left(a_{j}, x, b_{j}\right)$.

4. Hitung semua keluaran di node pada lapisan keluaran dengan persamaan (2).

\section{Firefly Algorithm}

Menurut [13], Firefly Algorithm (FA) terispirasi oleh perilaku sosial dan cara komunikasi sekelompok kunang-kunang (firefly) melalui cahaya di bagian ekornya. Sebagian besar kunang-kunang menghasilkan kilatan cahaya pendek dan berirama, yang memiliki pola unik pada setiap spesies. Cahaya berkilau kunang-kunang memiliki dua fungsi, yaitu: menarik kunang-kunang lain untuk dijadikan pasangan dan menjebak calon mangsa.

FA dikembangkan oleh Xin-She Yang pada tahun 2007, dan FA memiliki tiga aturan berikut [8]:

1. Semua kunang-kunang adalah unisex sehingga setiap kunang-kunang akan tertarik satu sama laindan tidak memilih jenis kelamin.

2. Daya tarik (attractiveness) kunang-kunang bersifat proposional dengan intensitas cahaya (light intensity) yang dimilikinya. Kunang-kunang yang memiliki intensitas cahaya rendah (redup) akan tertarik dan bergerak ke kunang-kunang yang memiliki intensitas cahaya yang lebih tinggi (terang). Jika tidak ada kunang-kunang bercahaya lebih terang dari dirinya, maka kunang-kunangtersebut akan bergerak secara acak; dan

3. Intensitas cahaya kunang-kunang ditentukan oleh fungsi objektif. Untuk masalah maksimasi, intensitas cahaya proporsional dengan nilai fungsi objektif.

\section{A. Intensitas Cahaya dan Keatraktifan Firefly}

Attractiveness (daya tarik) seekor kunang-kunang proposional dengan intensitas cahayanya yang dilihat oleh kunang-kunang lain. Fungsi keatraktifan [8] dirumuskan dengan persamaan (5):

$$
\beta(r)=\beta_{0} e^{-\gamma r^{2}}
$$

dengan $\beta(r)$ adalah attractiveness kunang-kunang pada jarak $r, \beta_{0}$ adalah attractiveness kunang-kunang pada $r=0, \gamma$ adalah koefisien daya serap cahaya (light absorption), dan $r$ adalah jarak antara dua kunang-kunang.

\section{B. Jarak antar Firefly}

Jarak antara dua kunang-kunang $i$ dan $j$ pada posisi koordinat $x_{i}$ dan $x_{j}$ adalah jarak euclideanyang dirumuskan dengan persamaan (6) : 


$$
r_{i j}=\left\|x_{i}-x_{j}\right\|=\sqrt{\sum_{k=1}^{d}\left(x_{i, k}-x_{j, k}\right)^{2}}
$$

dengan $x_{i, k}$ adalah komponen ke- $k$ dari firefly ke- $i\left(x_{i}\right)$ dan $x_{j, k}$ adalah komponen ke- $k$ dari firefly ke-j $\left(x_{j}\right)$, dan d adalah banyaknya komponen dari individu firefly.

\section{Pergerakan Firefly}

Gerakan kunang-kunang $i$ yang tertarik ke kunang-kunang $j$ (yang lebih terang atau memiliki attractiveness lebih tinggi) dirumuskan dengan persamaan (7):

$$
x_{i}(\text { baru })=x_{i}+\beta_{0} e^{-\gamma r_{i j}^{2}}\left(x_{j}-x_{i}\right)+\alpha\left(\operatorname{rand}-\frac{1}{2}\right)
$$

dengan $\beta_{0} e^{-\gamma r_{i j}^{2}}\left(x_{j}-x_{i}\right)$ adalah perpindahan firefly yang terjadi karena adanya daya tarik (keatraktifan firefly) sedangkan bagian ketiga dalam penjumlahan tersebut adalah proses pengacakan parameter $\alpha$ dan rand adalah fungsi pembangkit bilangan real secara random berdistribusi uniform pada interval [0,1]. Padaumumnya, digunakan $\beta_{0}=1, \alpha \in$ $[0,1]$, dan $\gamma \in[0, \infty)$.

Firefly terbaik yakni firefly yang memiliki intensitas cahaya paling tinggi. Firefly tersebut juga melakukan pergerakan secara random yaitu dengan persamaan (8):

$$
x_{i}(\operatorname{baru})=x_{i}+\alpha\left(\operatorname{rand}-\frac{1}{2}\right)
$$

Langkah-langkah dasar Firefly Algorithm adalah sebagai berikut [8]:

1. Input parameter Firefly Algorithm.

2. Membangkitkan populasi awal berupa bilangan real yang diambil secara random sebanyak mfirefly.

3. Hitung intensitas cahaya tiap firefly $I(x)$ berdasarkan nilai fungsi tujuan $f(x)$.

4. Membandingkan intensitas cahaya tiap firefly dengan firefly lainnya. Apabila terdapat firefly yangmemiliki intensitas cahaya lebih besar, lakukan update firefly dengan menggunakan persamaan pergerakan firefly.

5. Menentukan firefly terbaik. Firefly dengan intesitas paling tinggi merupakan firefly terbaik.

6. Melakukan proses pergerakan kepada firefly terbaik dan menggabungkannya dengan firefly yang lain untuk menjadi populasi awal pada iterasi selanjutnya.

7. Jika batas iterasi dipenuhi, maka proses berhenti. Jika tidak, maka proses kembali ke langkah 3 


\section{Peramalan Menggunakan ELM-FA}

Langkah-langkah yang digunakan dalam penelitian ini adalah sebagai berikut:

1. Studi pustaka mengenai masalah yang berkaitan dengan nilai tukar rupiah terhadap dolar Amerika Serikat, peramalan (forecasting), jaringan saraf tiruan metode extreme learning machine (ELM), dan firefly algorithm (FA).

2. Hybrid jaringan saraf tiruan metode extreme learning machine dan firefly algorithm untuk meramalkan nilai tukar rupiah terhadap dolar Amerika Serikat dengan langkah-langkah sebagai berikut:

i. Menghimpun data kurs (nilai tukar) rupiah terhadap dolar Amerika Serikat. Data yang dihimpun bersumber dari www.bi.go.id. Komposisi pembagian data untuk pelatihan (training) dan uji validasi adalah sebagai berikut:

- $\quad 70 \%$ dari total data digunakan sebagai data pelatihan (training).

- $\quad 30 \%$ dari total data digunakan sebagai data uji validasi.

ii. Melakukan proses normalisasi data kurs ke interval $(0,1)$. Proses tersebut untuk mengurangi kompleksitas data, dan memudahkan dalam memodifikasi data.

iii. Membuat rancangan pola data yang akan digunakan sebagai nilai input dalam jaringan ELM-FA. Karena data kurs yang diperoleh merupakan data kurs harian kecuali hari sabtu dan minggu, maka jumlah node masukan yang dipilih sebanyak empat. Jumlah node masukan tersebut mempresentasikan jumlah hari dalam satu minggu dengan target hari ke-5. Format pola data untuk pelatihan (509 pola data) disajikan pada Tabel 1.

Tabel 1 Format Pola Data Untuk Pelatihan

\begin{tabular}{|c|c|c|c|c|c|}
\hline Pola & $x_{1}$ & $x_{2}$ & $x_{3}$ & $x_{4}$ & Target \\
\hline 1 & Data ke-1 & Data ke-2 & Data ke-3 & Data ke-4 & Data ke-5 \\
\hline 2 & Data ke-2 & Data ke-3 & Data ke-4 & Data ke-5 & Data ke-6 \\
\hline 3 & Data ke-3 & Data ke-4 & Data ke-5 & Data ke-6 & Data ke-7 \\
\hline$\vdots$ & $\vdots$ & $\vdots$ & $\vdots$ & $\vdots$ & $\vdots$ \\
\hline 509 & Data ke-509 & Data ke-510 & Data ke-511 & Data ke-512 & Data ke-513 \\
\hline
\end{tabular}

iv. Mendesain arsitektur jaringan saraf tiruan yang terdiri dari input layer, hidden layer, dan output layer. Rancangan jumlah neuron pada setiap lapisan adalah sebagai berikut:

a. Jumlah neuron yang digunakan pada input layer sebanyak empat.

b. Jumlah neuron yang digunakan pada hidden layer sama dengan jumlah neuron yangdigunakan pada input layer

c. Jumlah neuron yang digunakan pada output layer sebanyak satu. 
v. Melakukan proses pelatihan (training) metode ELM-FA untuk memperoleh nilai bobot dan bias.

a. Masukkan data pelatihan (training) yang telah dinormalisasi.

b. Inisiasi nilai-nilai parameter yang digunakan pada jaringan, yaitu banyaknya firefly, $\alpha, \beta$, maksimum iterasi, dan batas MSE.

c. Membangkitkan populasi awal pada firefly. Menentukan populasi awal dengan membangkitkan bilangan real secara random pada interval $(-1,1)$ sebanyak jumlah firefly.

d. Konversi individu firefly dalam FA menjadi bobot masukan $(a)$ dan bias (b) dalam ELM.

e. Menghitung keluaran dari node pada lapisan tersembunyi. Fungsi aktivasi yangdigunakan pada ELM adalah sigmoid biner [14].

f. Menghitung bobot akhir keluaran $(\beta)$.

g. Menghitung keluaran jaringan $(Y)$.

i. Memeriksa stopping condition. Terdapat dua kondisi stopping condition, yaitu jumlah iterasi sudah mencapai batas maksimum atau nilai error (MSE) pada pelatihan jaringan sudah terpenuhi.

j. Jika error atau jumlah iterasi belum terpenuhi, maka proses pelatihan lanjut ke langkah (2.e.x). Jika error atau jumlah iterasi telah terpenuhi maka simpan individufirefly dan $\beta$ yang merupakan solusi, kemudian lanjut ke langkah (vi).

k. Menghitung nilai fitness dari tiap individu firefly menggunakan persamaan:

$$
f(x)=\frac{1}{1+\operatorname{MSE}(x)}
$$

1. Transformasi nilai fitness menjadi nilai intensitas cahaya firefly. Intensitas cahaya sebanding dengan nilai fitness.

m. Membandingkan intensitas cahaya firefly ke- $i$ dengan firefly ke- $j$ seperti berikut:

- Jika intensitas cahaya firefly ke-i lebih besar dari firefly ke-j, ulangi langkah inidengan $j=j+1$.

- Jika intensitas cahaya firefly ke-i lebih kecil dari firefly ke-j, maka hitung jarak firefly ke- $i$ ke firefly ke- $j$, kemudian hitung nilai keatraktifan firefly dan lakukan pergerakan dari firefly ke-i menuju firefly ke-j, kemudian ulangi langkah ini dengan $j=j+1$.

Ketika $j$ lebih besar dari jumlah firefly, maka lanjut ke langkah $n$.

$\mathrm{n}$. Ulangi langkah $m$ dengan $i=i+1$ sampai semua firefly dibandingkan.

o. Tentukan firefly terbaik yaitu firefly dengan intensitas cahaya paling besar. Setelah itu lakukan pergerakan pada firefly terbaik, kemudian lakukan kembali langkah o. 
vi. Melakukan uji validasi. Format data untuk validasi disajikan pada Tabel 2.

a. Masukkan data untuk uji validasi yang telah dinormalisasi.

b. Masukkan bobot dan bias yang diperoleh dari proses pelatihan.

c. Menghitung keluaran dari jaringan $(Y)$ dan MSE.

vii. Melakukan denormalisasi data.

Tabel 2 Format Pola Data Untuk Uji Validasi

\begin{tabular}{|c|c|c|c|c|c|}
\hline Pola & $x_{1}$ & $x_{2}$ & $x_{3}$ & $x_{4}$ & Target \\
\hline 1 & Data ke-514 & Data ke-515 & Data ke-516 & Data ke-517 & Data ke-518 \\
\hline 2 & Data ke-515 & Data ke-516 & Data ke-517 & Data ke-518 & Data ke-519 \\
\hline 3 & Data ke-516 & Data ke-517 & Data ke-518 & Data ke-519 & Data ke-520 \\
\hline$\vdots$ & $\vdots$ & $\vdots$ & $\vdots$ & $\vdots$ & $\vdots$ \\
\hline 217 & Data ke-730 & Data ke-731 & Data ke-732 & Data ke-733 & Data ke-734 \\
\hline
\end{tabular}

3. Membuat program hybrid jaringan saraf tiruan metode extreme learning machine dan fireflyalgorithm.

4. Mengimplementasikan program untuk peramalan nilai tukar rupiah terhadap dolar AmerikaSerikat .

\section{Hasil dan Pembahasan}

Pada penelitian ini digunakan bahasa pemrograman $C++$ untuk melakukan semua proses yang telah dijelaskan pada subbab sebelumnya. Kemudiandilakukan simulasi prediksi peramalan nilai tukar rupiah terhadap dolar Amerika Serikat. Langkah pertama yang diminta program ialah memasukkan beberapa parameter yaitu jumlah maksimum iterasi, nilai batas MSE, keaktraktifan awal, koefisien udara, koefisien random, dan jumlah firefly.

Nilai keaktraktifan awal yang dipilih untuk simulasi ini sebesar 1, dan batas MSE sebesar 0.0001 . Beberapa variasi nilai parameter yang digunakan untuk memperoleh nilai MSE terkecil pada proses pelatihan disajikan pada Tabel 3, Tabel 4, dan Tabel 5. Validasi denganindividu firefly sebanyak 3 disajikan pada Tabel 3. 
Tabel 3 Hasil Pelatihan dan Uji Validasi untuk Beberapa Nilai Parameter dengan popsize $=3$

\begin{tabular}{|c|c|c|c|c|c|c|}
\hline No. & $\begin{array}{c}\text { Koefisien } \\
\text { random }\end{array}$ & $\begin{array}{c}\text { Koefisien } \\
\text { udara }\end{array}$ & $\begin{array}{l}\text { Maks } \\
\text { iterasi }\end{array}$ & MSE terkecil & $\begin{array}{c}\text { Iterasi } \\
\text { Berhenti }\end{array}$ & MSE Uji \\
\hline 1 & \multirow{6}{*}{0.01} & \multirow{2}{*}{0.01} & 10 & 0.000566796 & 10 & 0.0000905586 \\
\hline 2 & & & 200 & 0.000512566 & 200 & 0.0000857925 \\
\hline 3 & & \multirow{2}{*}{0.2} & 10 & 0.000571375 & 10 & 0.0000914413 \\
\hline 4 & & & 200 & 0.000514431 & 200 & 0.000086081 \\
\hline 5 & & \multirow{2}{*}{0.5} & 10 & 0.000559643 & 10 & 0.0000895854 \\
\hline 6 & & & 200 & 0.000558039 & 200 & 0.0000899909 \\
\hline 7 & \multirow{6}{*}{0.2} & \multirow{2}{*}{0.01} & 10 & 0.000527438 & 10 & 0.0000874421 \\
\hline 8 & & & 200 & 0.000486166 & 200 & 0.0000861531 \\
\hline 9 & & \multirow{2}{*}{0.2} & 10 & 0.000576913 & 10 & 0.0000936482 \\
\hline 10 & & & 200 & 0.00050587 & 200 & 0.0000855961 \\
\hline 11 & & \multirow{2}{*}{0.5} & 10 & 0.000594398 & 10 & 0.000109479 \\
\hline 12 & & & 200 & 0.000508325 & 200 & 0.0000842686 \\
\hline 13 & \multirow{6}{*}{0.5} & \multirow{2}{*}{0.01} & 10 & 0.000549267 & 10 & 0.0000868391 \\
\hline 14 & & & 200 & 0.00050463 & 200 & 0.0000835798 \\
\hline 15 & & \multirow{2}{*}{0.2} & 10 & 0.000554622 & 10 & 0.000093351 \\
\hline 16 & & & 200 & 0.00049644 & 200 & 0.000084138 \\
\hline 17 & & \multirow{2}{*}{0.5} & 10 & 0.000970305 & 10 & 0.000149023 \\
\hline 18 & & & 200 & 0.00188459 & 200 & 0.000523052 \\
\hline
\end{tabular}

Tabel 4 Hasil Pelatihan dan Uji Validasi untuk Beberapa Nilai Parameter dengan popsize $=10$

\begin{tabular}{|c|c|c|c|c|c|c|}
\hline No. & $\begin{array}{c}\text { Koefisien } \\
\text { random }\end{array}$ & $\begin{array}{c}\text { Koefisien } \\
\text { udara }\end{array}$ & $\begin{array}{l}\text { Maks } \\
\text { Iterasi }\end{array}$ & $\begin{array}{l}\text { MSE } \\
\text { terkecil }\end{array}$ & $\begin{array}{c}\text { Iterasi } \\
\text { Berhenti }\end{array}$ & MSE Uji \\
\hline 1 & \multirow{6}{*}{0.01} & \multirow{2}{*}{0.01} & 10 & 0.000538022 & 10 & 0.000089694 \\
\hline 2 & & & 200 & 0.000516493 & 200 & 0.0000849318 \\
\hline 3 & & \multirow{2}{*}{0.2} & 10 & 0.000513193 & 10 & 0.0000904561 \\
\hline 4 & & & 200 & 0.000516851 & 200 & 0.0000859038 \\
\hline 5 & & \multirow{2}{*}{0.5} & 10 & 0.000524063 & 10 & 0.000084505 \\
\hline 6 & & & 200 & 0.000520434 & 200 & 0.0000845381 \\
\hline
\end{tabular}




\begin{tabular}{|c|c|c|c|c|c|c|}
\hline No. & $\begin{array}{c}\text { Koefisien } \\
\text { random }\end{array}$ & $\begin{array}{c}\text { Koefisien } \\
\text { udara }\end{array}$ & $\begin{array}{l}\text { Maks } \\
\text { Iterasi }\end{array}$ & $\begin{array}{l}\text { MSE } \\
\text { terkecil }\end{array}$ & $\begin{array}{c}\text { Iterasi } \\
\text { Berhenti }\end{array}$ & MSE Uji \\
\hline 7 & \multirow{6}{*}{0.2} & \multirow{2}{*}{0.01} & 10 & 0.000523433 & 10 & 0.0000850836 \\
\hline 8 & & & 200 & 0.000503482 & 200 & 0.000084779 \\
\hline 9 & & \multirow{2}{*}{0.2} & 10 & 0.000512076 & 10 & 0.0000908442 \\
\hline 10 & & & 200 & 0.000502218 & 200 & 0.0000862579 \\
\hline 11 & & \multirow{2}{*}{0.5} & 10 & 0.000521708 & 10 & 0.000088783 \\
\hline 12 & & & 200 & 0.000494469 & 200 & 0.0000894164 \\
\hline 13 & \multirow{6}{*}{0.5} & \multirow{2}{*}{0.01} & 10 & 0.000527498 & 10 & 0.0000849267 \\
\hline 14 & & & 200 & 0.000517428 & 200 & 0.0000857581 \\
\hline 15 & & \multirow[b]{2}{*}{0.2} & 10 & 0.000521567 & 10 & 0.0000868285 \\
\hline 16 & & & 200 & 0.00051625 & 200 & 0.0000852438 \\
\hline 17 & & \multirow[b]{2}{*}{0.5} & 10 & 0.000536887 & 10 & 0.000086073 \\
\hline 18 & & & 200 & 0.000516104 & 200 & 0.0000868335 \\
\hline
\end{tabular}

Tabel 5 Hasil Pelatihan dan Uji Validasi untuk Beberapa Nilai Parameter dengan popsize $=20$

\begin{tabular}{|c|c|c|c|c|c|c|}
\hline No. & $\begin{array}{c}\text { Koefisien } \\
\text { random }\end{array}$ & $\begin{array}{c}\text { Koefisien } \\
\text { udara }\end{array}$ & $\begin{array}{l}\text { Maks } \\
\text { Iterasi }\end{array}$ & MSE terkecil & $\begin{array}{c}\text { Iterasi } \\
\text { Berhenti }\end{array}$ & MSE Uji \\
\hline 1 & \multirow{6}{*}{0.01} & \multirow{2}{*}{0.01} & 10 & 0.00049588 & 10 & 0.0000863536 \\
\hline 2 & & & 200 & 0.000486444 & 200 & 0.0000854881 \\
\hline 3 & & \multirow{2}{*}{0.2} & 10 & 0.00052302 & 10 & 0.0000844497 \\
\hline 4 & & & 200 & 0.000521011 & 200 & 0.0000844467 \\
\hline 5 & & \multirow{2}{*}{0.5} & 10 & 0.000519636 & 10 & 0.0000846075 \\
\hline 6 & & & 200 & 0.000518054 & 200 & 0.0000854692 \\
\hline 7 & \multirow{6}{*}{0.2} & \multirow{2}{*}{0.01} & 10 & 0.000517768 & 10 & 0.0000885977 \\
\hline 8 & & & 200 & 0.000494787 & 200 & 0.0000891541 \\
\hline 9 & & \multirow{2}{*}{0.2} & 10 & 0.000515993 & 10 & 0.0000855428 \\
\hline 10 & & & 200 & 0.000516314 & 200 & 0.0000873433 \\
\hline 11 & & \multirow{2}{*}{0.5} & 10 & 0.000502455 & 10 & 0.0000866318 \\
\hline 12 & & & 200 & 0.000480513 & 200 & 0.0000854107 \\
\hline
\end{tabular}




\begin{tabular}{|c|c|c|c|c|c|c|}
\hline No. & $\begin{array}{c}\text { Koefisien } \\
\text { random }\end{array}$ & $\begin{array}{c}\text { Koefisien } \\
\text { udara }\end{array}$ & $\begin{array}{l}\text { Maks } \\
\text { Iterasi }\end{array}$ & MSE terkecil & $\begin{array}{c}\text { Iterasi } \\
\text { Berhenti }\end{array}$ & MSE Uji \\
\hline 13 & \multirow{6}{*}{5} & \multirow{2}{*}{0.01} & 10 & 0.000508661 & 10 & 0.0000877784 \\
\hline 14 & & & 200 & 0.000482172 & 200 & 0.00008416 \\
\hline 15 & & \multirow{2}{*}{0.2} & 10 & 0.000521808 & 10 & 0.0000864831 \\
\hline 16 & & & 200 & 0.000514985 & 200 & 0.00008717 \\
\hline 17 & & \multirow{2}{*}{0.5} & 10 & 0.000539409 & 10 & 0.0000879365 \\
\hline 18 & & & 200 & 0.000516516 & 200 & 0.0000863552 \\
\hline
\end{tabular}

Setelah proses pelatihan dan uji validasi dijalankan dengan semua variasi nilai parameter, dapat diketahui bahwa MSE pelatihan terkecil dari ketiga variasi jumlah firefly sebesar 0.000480513. Nilai MSEtersebut diperoleh ketika nilai parameter koefisien random $=0.2$, koefisien udara $=0.5$, jumlah firefly $=20$, dengan iterasi sebanyak 200. Sehingga nilai bobot dan bias yang diperoleh dari nilai-nilai parameter tersebut dapat digunakan selanjutnya untuk prediksi kurs masa mendatang. Nilai MSE uji validasi relatif kecil menunjukkan bahwa hasil pelatihan ELM-FA mampu memprediksi data uji dengan baik. Masing- masing nilai bobot dan bias optimal pelatihan dari ketiga variasi jumlah firefly disajikan pada Tabel 6.

Tabel 6 Firefly Terbaik pada Proses Pelatihan

\begin{tabular}{|c|c|c|c|c|c|c|c|}
\hline \multirow{2}{*}{$\begin{array}{l}\text { Jumlah } \\
\text { Firefly }\end{array}$} & & \multicolumn{4}{|c|}{ Bobot input $\left(a_{i j}\right)$} & \multirow{2}{*}{ Bias $(b)$} & \multirow{2}{*}{$\operatorname{Beta}(\beta)$} \\
\hline & & $h_{1}$ & $h_{2}$ & $h_{3}$ & $h_{4}$ & & \\
\hline \multirow{4}{*}{3} & $x_{1}$ & -0.5578 & 0.29479 & 0.639835 & -1.31209 & -1.09909 & 1.06698 \\
\hline & $x_{2}$ & -0.77884 & -0.02055 & 0.029552 & -0.27233 & -1.02821 & 13.2631 \\
\hline & $x_{3}$ & -1.75665 & -0.06592 & -0.15412 & 0.023328 & -1.61653 & -15.5331 \\
\hline & $x_{4}$ & -0.23052 & 0.262109 & -0.12519 & 0.095633 & -0.7477 & -3.63348 \\
\hline \multirow{4}{*}{10} & $x_{1}$ & -0.21019 & 0.311438 & 0.055783 & 0.440858 & -0.06539 & -6.3925 \\
\hline & $x_{2}$ & 0.241308 & 0.365007 & 0.675886 & 0.358912 & -0.24 & 20.7487 \\
\hline & $x_{3}$ & 0.115124 & 0.291919 & -0.71525 & 0.239801 & 0.399923 & 1.362 \\
\hline & $x_{4}$ & 0.282199 & -0.35285 & 0.098394 & -0.70263 & -0.60476 & -19.4183 \\
\hline & $x_{1}$ & -0.19271 & 0.952337 & 0.191217 & 0.486552 & -0.00041 & 7.97772 \\
\hline & $x_{2}$ & 0.108056 & 0.900936 & 0.767976 & 0.327668 & -0.12664 & 9.14708 \\
\hline
\end{tabular}




\begin{tabular}{|l|l|l|l|l|l|l|l|}
\cline { 2 - 7 } 20 & $x_{3}$ & 0.106962 & 0.274228 & 0.929668 & -0.27735 & -0.05123 & -7.2355 \\
\cline { 2 - 8 } & $x_{4}$ & 0.29582 & -0.43579 & -0.11609 & -0.40556 & -0.19156 & -10.474 \\
\hline
\end{tabular}

Berdasarkan nilai bobot dan bias tersebut, diperoleh nilai prediksi hasil uji validasi yang disajikanpada Tabel 7.

Tabel 7 Nilai Keluaran Hasil Uji Validasi

\begin{tabular}{|c|c|c|c|c|c|}
\hline \multirow{2}{*}{ Pola } & \multirow{2}{*}{ Tanggal } & \multicolumn{3}{|c|}{ Hasil Prediksi Data Uji (persentase error $)$} & \multirow{2}{*}{ Fakta Kurs } \\
\cline { 3 - 5 } & & 3 firefly & 10 firefly & 20 firefly & \\
\hline \multirow{2}{*}{1} & 8 Feb 17 & $\begin{array}{c}\text { Rp13327.6 } \\
(0.070 \%)\end{array}$ & $\begin{array}{c}\text { Rp13329.5 } \\
(0.056 \%)\end{array}$ & $\begin{array}{c}\text { Rp13330.6 } \\
(0.047 \%)\end{array}$ & Rp13337 \\
\hline 2 & 9 Feb 17 & $\begin{array}{c}\text { Rp13342.4 } \\
(0.258 \%)\end{array}$ & $\begin{array}{c}\text { Rp13342.7 } \\
(0.260 \%)\end{array}$ & $\begin{array}{c}\text { Rp13343.3 } \\
(0.265 \%)\end{array}$ & Rp13308 \\
\hline 3 & 10 Feb 17 & $\begin{array}{c}\text { Rp13314.2 } \\
(0.028 \%)\end{array}$ & $\begin{array}{c}\text { Rp13315.5 } \\
(0.018 \%)\end{array}$ & $\begin{array}{c}\text { Rp13315.2 } \\
(0.021 \%)\end{array}$ & Rp13318 \\
\hline$\vdots$ & $\vdots$ & $\vdots$ & $\vdots$ & $\vdots$ & $\vdots$ \\
\hline 215 & 4 Jan 18 & $\begin{array}{c}\text { Rp13503.3 } \\
(0.217 \%)\end{array}$ & $\begin{array}{c}\text { Rp13502.8 } \\
(0.213 \%)\end{array}$ & $\begin{array}{c}\text { Rp13504.6 } \\
(0.227 \%)\end{array}$ & Rp13474 \\
\hline 216 & 5 Jan 18 & $\begin{array}{c}\text { Rp13477.4 } \\
(0.540 \%)\end{array}$ & $\begin{array}{c}\text { Rp13479.7 } \\
(0.557 \%)\end{array}$ & $\begin{array}{c}\text { Rp13479.8 } \\
(0.558 \%)\end{array}$ & Rp13405 \\
\hline 217 & 8 Jan 18 & $\begin{array}{c}\text { Rp13410 } \\
(0.097 \%)\end{array}$ & $\begin{array}{c}\text { Rp13407.8 } \\
(0.080 \%)\end{array}$ & $\begin{array}{c}\text { Rp13414.1 } \\
(0.127 \%)\end{array}$ & Rp13397 \\
\hline
\end{tabular}

Selanjutnya akan disajikan Grafik Nilai Keluaran Hasil Uji Validasi untuk ketiga variasi jumlah firefly pada Gambar 2, Gambar 3, dan Gambar 4. Grafik Nilai Keluaran Hasil Uji Validasi 3 firefly disajikan pada Gambar 2. 


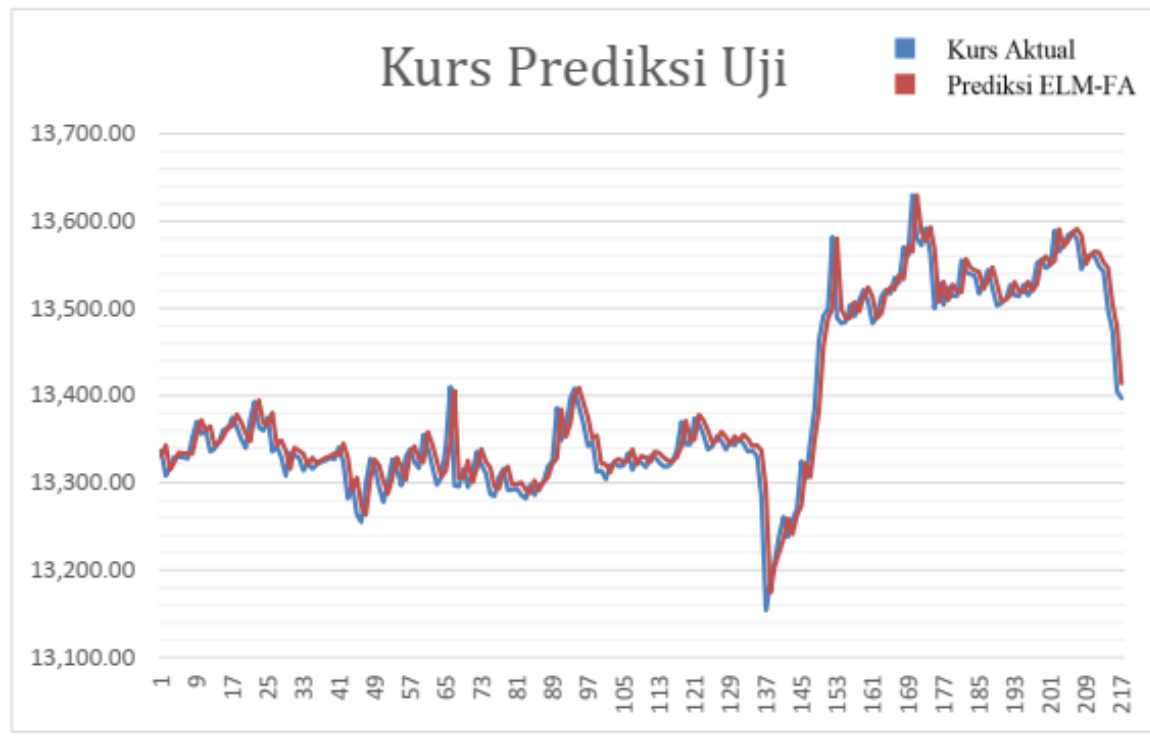

Gambar 2 Grafik Nilai Keluaran Hasil Uji Validasi dengan popsize $=3$

Selanjutnya, disajikan Grafik Nilai Keluaran Hasil Uji Validasi 10 firefly pada Gambar 3.

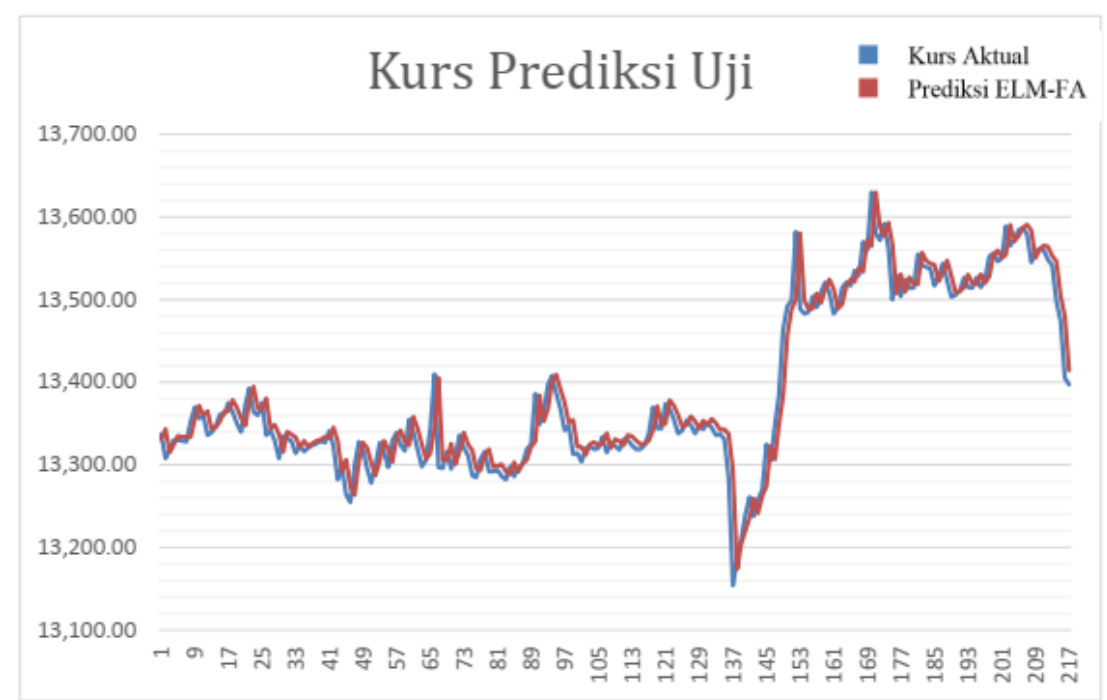

Gambar 3 Grafik Nilai Keluaran Hasil Uji Validasi dengan popsize $=10$ 


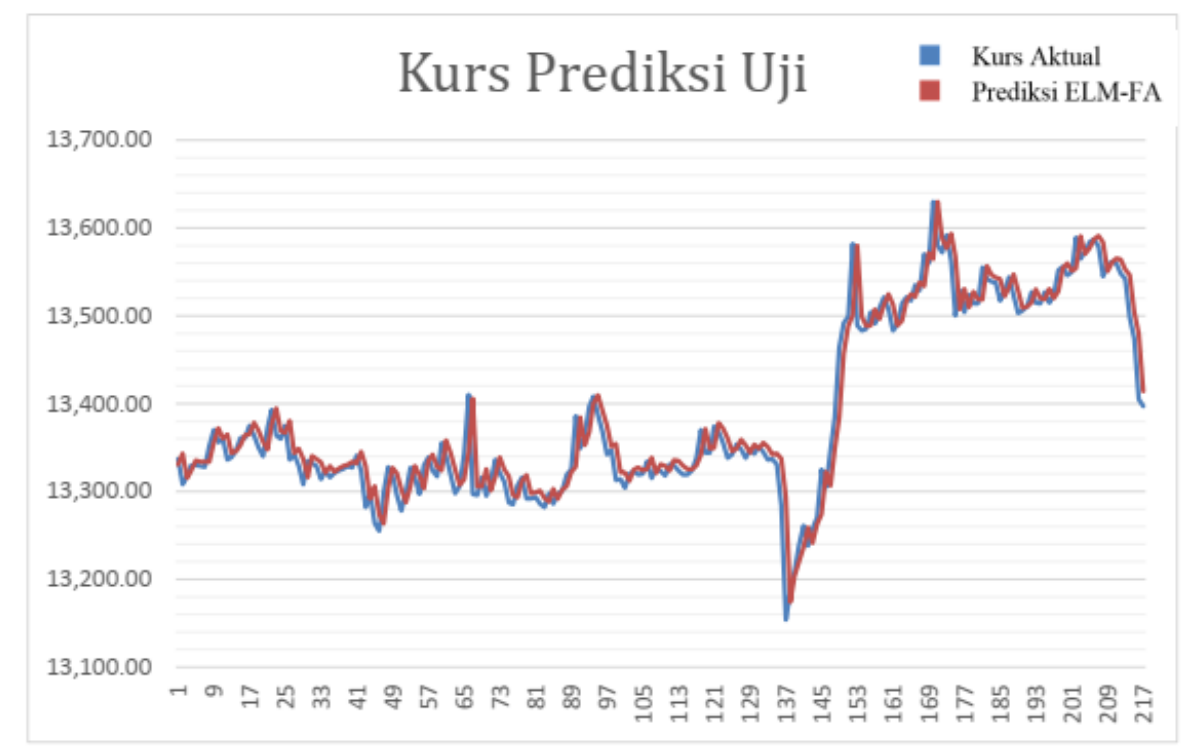

Gambar 4 Grafik Nilai Keluaran Hasil Uji Validasi dengan popsize $=20$

Dapat diketahui dari beberapa pola data hasil uji validasi pada Tabel 7, nilai prediksi pada pola data ke-3 menunjukkan hasil mendekati nilai sebenarnya yaitu Rp13314.2 (3 firefly) dengan persentase error sebesar 0.028\%, Rp13315.5 (10 firefly) dengan persentase error sebesar $0.018 \%$, dan Rp13315.2 (20 firefly) dengan persentase error sebesar $0.021 \%$. Hal ini menunjukkan bahwa kinerja ELM-FA dalam peramalan nilai kurs dapat dikatakan baik karena selisih error yang dihasilkan relatif kecil. Sehingga program ini dapat digunakan untuk peramalan nilai tukar rupiah selanjutnya. Rata-rata persentase error uji validasi yang dihasilkan oleh masing-masing firefly terbaik dari ketiga variasi jumlah firefly, yaitu $0.1395 \%$ (3 firefly), $0.1431 \%$ (10 firefly), dan $0.1379 \%$ (20 firefly).

Selanjutnya, dilakukan prediksi nilai tukar rupiah untuk lima hari akan datang yaitu tanggal 9, 10,11, 12, dan 13 Januari 2018 menggunakan bobot dan bias optimal pelatihan (MSE pelatihan sebesar 0.000480513). Hasil prediksi disajikan pada Tabel 8.

Untuk memperoleh hasil prediksi pada tanggal 9 Januari 2018, digunakan data input kurs empat hari sebelumnya. Sedangkan hasil prediksi yang diperoleh pada tanggal 9 Januari 2018 digunakan untuk memprediksi kurs pada tanggal 10 Januari 2018. Sehingga untuk memprediksi kurs pada tanggal 13 Januari2018 (lima hari akan datang), digunakan hasil prediksi kurs pada tanggal 9-12 Januari 2018 sebagai data input jaringan ELM. 
Tabel 8 Nilai Keluaran Hasil Prediksi

\begin{tabular}{|c|c|c|}
\hline No. & Tanggal & Hasil Prediksi \\
\hline 1 & 9 Jan 18 & Rp13404.5 \\
\hline 2 & 10 Jan 18 & Rp13411.1 \\
\hline 3 & 11 Jan 18 & Rp13415.6 \\
\hline 4 & 12 Jan 18 & Rp13419.8 \\
\hline 5 & 13 Jan 18 & Rp13424.1 \\
\hline
\end{tabular}

\section{Kesimpulan}

Berdasarkan implementasi program dan simulasi untuk beberapa nilai parameter, diperoleh MSEpelatihan ELM-FA terkecil sebesar 0.000480513 dengan MSE uji validasi sebesar 0.0000854107. Nilai MSE relatif kecil menunjukkan bahwa jaringan ELM-FA mampu mengenali pola data dan mampu memprediksi data uji dengan baik. MSE pelatihan terkecil diperoleh ketika nilai parameter koefisien random $=0.2$, koefisien udara $=0.5$, jumlah firefly $=20$, dengan iterasi sebanyak 200. Nilai bobot dan bias yang diperoleh dari nilai-nilai parameter tersebut tersebut cukup baik digunakan untuk prediksi kurs masamendatang.

\section{Daftar Pustaka}

[1] Samuelson, P. A., dan Nordhaus, W. D., 1994, Makroekonomi, Edisi 14, Erlangga, Jakarta.

[2] Kuncoro, M., 1996, Manajemen Keuangan Internasional, Edisi 1, BPFEYogyakarta, Yogyakarta.

[3] Triyono, 2008, Analisis Perubahan Kurs Rupiah terhadap Dolar Amerika, Jurnal Ekonomi Pembangunan, Vol 9, 156-167.

[4] Jauhari, D., Hanafi, A., Yuniarsa, M. F. A., Satria, A. R., Luqman, H., dan Cholissodin, I., 2016, Prediksi Nilai Tukar Rupiah terhadap US Dollar menggunakan Metode Genetic Programming, Jurnal Teknologi Informasi dan Ilmu Komputer 3(4) $: 285$.

[5] Jauhari, D., Himawan, A., dan Dewi, C., 2016. Prediksi Distribusi Air PDAM Menggunakan Metode Jaringan Syaraf Tiruan Backpropagation di PDAM Kota Malang. Jurnal Teknologi Informasi dan Ilmu Komputer (JTIIK), 3(2), 85-89.

[6] Huang, G.-B., Zhu, Q.-Y., dan Siew, C.-K, 2006, Extreme Learning Machine: Theory and Applications, Neurocomputing, 70, 489-501. 
[7] Khotimah, B. K., R., Eka M., dan Yulianarta, H., 2010, Kinerja Metode Extreme Learning Machine (ELM)pada Sistem Peramalan, Jurnal SimanteC, Vol 1, 186-191.

[8] Yang, X. S., 2010, Engineering Optimization: An Introduction with Metaheuristic Applications, Wilwy \& Sons Inc, New Jersey.

[9] Apostolopoulos, T., dan Vlachos, A., 2011, Application of the Firefly Algorithm for Solving the EconomicEmissions Load Dispatch Problem, International Journal of Combinatorics, Vol 2011, 23.

[10] Sartono, A., 1996, Manajemen Keuangan, Edisi 3, BPFE-Yogyakarta, Yogyakarta.

[11] Reksoprajitno, S., 1995, Ekonomi Internasional: Pengantar Lalu-Lintas Pembayaran Internasional, Edisi2, Liberty Yogyakarta, Yogyakarta.

[12] Sun, Z-L., Choi, T.-M., Au, K.-F., dan Yu, Y., 2008, Sales Forecasting using Extreme Learning Machinewith Applications in Fashion Retailing, Decision Support Systems, 46, 411-419.

[13] Suyanto, 2017, Swarm Intelligence Komputasi Modern untuk Optimasi dan Big Data Mining, Edisi 1,Informatika Bandung, Bandung.

[14] Albadr, M.A.A., dan Tiun, S., 2017, Extreme Learning Machine: A Review, International Journal ofApplied Engineering Research, Vol 12, 4610-4623. 